\title{
Kualitas Telur Puyuh Jepang \\ (Coturnix coturnix japonica L.) berdasarkan Variabel pH telur, Indeks Kuning Telur (IKT) dan Indeks Putih Telur (IPT) setelah Penyimpanan yang Dilakukan Perendaman Pada Air Kapur Sebelum Penyimpanan
}

\author{
Muhammad Anwar Djaelani \\ Departemen Biologi, Fakultas Sains dan Matematika, Universitas Diponegoro \\ Jl. Prof Soedharto, SH, Tembalang, Semarang 50275 \\ muhammadanwardjaelani@ rocketmail.com
}

\begin{abstract}
Abstrak
Puyuh Jepang (Coturnix coturnix japonica L.) banyak dibudidayakan untuk diambil telurnya karena produktivitas telur yang tinggi. Nilai gizi telur puyuh tidak kalah dengan telur unggas lain, sehingga dapat menambah variasi dalam penyediaan sumber protein hewani. Telur merupakan salah satu bahan makanan yang hampir sempurna. Bahan makanan ini mengandung zat gizi lengkap antara lain protein, lemak, vitamin dan mineral. Telur segar yaitu telur yang baru diletakkan oleh induk disarangnya, mempunyai daya simpan yang pendek. Salah satu faktor yang menyebabkan rusaknya telur adalah lama waktu penyimpanan. Penelitian ini bertujuan untuk menganalisis kualitas telur puyuh berdasarkan pH Telur, nilai Indeks Kuning Telur (IKT), Indeks Putih Telur (IPT) setelah perendaman dengan air kapur. Sampel yang digunakan adalah telur puyuh yang diambil pada hari kedua peneluran. Digunakan Rancangan acak lengkap dengan 5 kelompok perlakuan yaitu P1 kelompok telur,diamati pada hari ke 2. P2 kelompok telur disimpan dan diamati pada hari ke 16. P3 kelompok telur direndam pada air kapur selama 1 menit, disimpan dan diamati pada hari ke 16. P4 kelompok telur disimpan dan diamati pada hari ke 30. P5 kelompok telur direndam pada air kapur selama 1 menit, disimpan dan diamati pada hari ke 30. Data yang diperoleh dianalisis menggunakan ANOVA dengan taraf signifikansi 5\%. Hasil penelitian menunjukkan semua variabel penelitian menenunjukkan penurunan seiring dengan bertambahnya waktu penyimpanan. Penurunan kualitas disebabkan faktor lamanya penyimpanan yang menyebabkan perubahan kondisi telur.
\end{abstract}

Kata kunci : Penyimpanan telur, pH telur, Indeks Kuning Telur, Indeks Putih Telur

\section{PENDAHULUAN}

Telur merupakan salah satu bahan makanan yang hampir sempurna. Bahan makanan ini mengandung zat gizi lengkap antara lain protein, lemak, vitamin dan mineral (Cornelia dkk., 2014). Puyuh Jepang (Coturnix coturnix japonica L.) banyak dibudidayakan untuk diambil telurnya karena produktivitas telur yang tinggi. Nilai gizi telur puyuh tidak kalah dengan telur unggas lain, sehingga dapat menambah variasi dalam penyediaan sumber protein hewani (Listyowati, 2009). Telur segar yaitu telur yang baru diletakkan oleh induk ayam disarangnya, mempunyai daya simpan yang pendek (Cornelia dkk., 2014). Pada suhu ruang telur hanya tahan 10 - 14 hari, setelah waktu tersebut telur mengalami perubahanperubahan kearah kerusakan seperti terjadinya penguapan kadar air melalui pori kulit telur yang berakibat berkurangnya berat telur, perubahan komposisi kimia dan terjadinya pengenceran isi telur (Melia, et. al., 2009). Lama penyimpanan menentukan kualitas telur, semakin lama telur disimpan, kualitas dan kesegaran telur semakin menurun (Haryoto, 2010). Hasil penelitian yang dilakukan oleh Fibrianti dkk. (2012) menunjukkan telur yang disimpan dalam suhu kamar selama 25 hari tanpa perlakuan apapun akan menurun kualitasnya.Telur yang dijual dipasaran tersimpan sekitar tujuh hari. Telur tersebut masih menunjukkan kualitas yang masih baik (Haryono, 2000).Perendaman dengan air kapur sebelum telur disimpan merupakan cara agar telur lebih tahan lama. Perendaman dalam larutan kapur merupakan salah satu cara pengawetan telur yang bertujuan mencegah penguapan air. (Koswara, 2009). 
Penurunan kualitas telur antara lain disebabkan masuknya mikroba-mokroba perusak ke dalam isi telur melalui pori-pori kerabang telur, menguapnya air dan gas karena pengaruh suhu lingkungan. Ruang penyimpan yang lembab akan menyebabkan kerabang berjamur. Lama penyimpanan menentukan kualitas telur (Haryono, 2000). Semakin lama disimpan, kualitas dan kesegaran telur semakin merosot. Selain karena $\mathrm{CO}_{2}$ pada telur yang banyak keluar mengakibatkan naiknya derajat keasaman, juga terjadi penguapan sehingga bobot telur menurun dan putih telur menjadi lebih encer. Selama penyimpanan, kantong udara mengalami keretakan sehingga albumin akan semakin encer (Haryoto, 2010).

Kualitas telur dapat ditentukan dengan mengamati Indeks Putih Telur (IPT) dan $\mathrm{pH}$ telur (Djaelani,2015). Kualitas telur juga bisa diamati dengan cara melakukan pengukuran terhadap Indeks Kuning Telur (IKT), Indeks Putih Telur (IPT) dan Haugh Unit (HU). (Fibrianti,2012).

Berdasarkan latar belakang di atas, untuk mendapatkan cara penyimpanan yang dapat mempertahankan kualitas telur lebih lama diperlukan penelitian cara penyimpanan telur. Diharapkan dapat ditemukan cara untuk mencegah invasi mikroba, mencegah penguapan serta mempertahankan kelembaban telur sehingga telur dapat bertahan kualitasnya dalam kurun waktu yang lebih lama. Penelitian ini bertujuan untuk mendapatkan cara penyimpanan telur yang dapat mempertahankan kualitas telur dalam kurun waktu yang lebih lama.

\section{BAHAN DAN METODE}

Penelitian ini dilakukan di Laboratorium Biologi Struktur dan Fungsi Hewan Jurusan Biologi Fakultas Sains dan Matematika Universitas Diponegoro Semarang Penelitian ini menggunakan metode eksperimental dengan rancangan acak lengkap (RAL) (Hanafiah, 2001)

Sampel yang digunakan pada penelitian ini adalah Telur puyuh Jepang sebanyak 50 butir, didapat dari peternakan puyuh di Klaten Jawa Tengah. Telur diamati pada hari kedua setelah telur keluarkan dari induknya. Penelitian ini mengggunakan Rancangan acak lengkap dengan 5 kelompok perlakuan masing-masing perlakuan diulang sebanyak 10 kali yaitu :

P1 kelompok telur,diamati pada hari ke 2.

P2 kelompok telur disimpan dan diamati pada hari ke 16.

P3 kelompok telur direndam pada air kapur selama 1 menit, disimpan dan diamati pada hari ke 16.

P4 kelompok telur disimpan dan diamati pada hari ke 30.

P5 kelompok telur direndam pada air kapur selama 1 menit, disimpan dan diamati pada hari ke 30 .

Variabel penelitian ini adalah $\mathrm{pH}$ telur, Indeks Kuning Telur (IKT) dan Indeks Putih Telur (IPT). Pengukuran $\mathrm{pH}$ telur dilakukan dengan cara mengocok telur hingga homogen kemudian ditentukan $\mathrm{pH}$ telur tersebut dengan menggunakan pH meter (Djaelani,2017). IKT didapat dengan mengukur membandingan tinggi kuning telur dengan garis tengah kuning telur (Fibrianti, 2012).IPT didapat dengan mengukur membandingan tinggi putih telur (albumin) kental dengan rata-rata garis tengahnya. Pengukuran dilakukan setelah kuning telur dipisahkan dengan hati-hati. (Djaelani,2015).

Data hasil penelitian diuji dengan menggunakan ANOVA. Uji dilanjutkan dengan uji Duncan untuk mengetahui adanya perbedaan antar kelompok dilakukan ( Santosa, 2015).

\section{HASIL DAN PEMBAHASAN}

Hasil penelitian meliputi Indeks Kuning Telur, Indeks Putih Telur dan $\mathrm{pH}$ Telur telur selama periode penelitian adalah sebagai berikut

Tabel 1. Hasil analisis data Kualitas telur puyuh Jepang (Coturnix coturnix japonica L.) berdasarkan variabel $\mathrm{pH}$ telur, indeks kuning telur dan indeks putih telur setelah penyimpanan yang dilakukan pencelupan pada air kapur sebelum penyimpanan

\begin{tabular}{llllll}
\hline \multirow{2}{*}{ Variabel } & \multicolumn{5}{c}{ Perlakuan } \\
\cline { 2 - 6 } & \multicolumn{1}{c}{ P1 } & \multicolumn{1}{c}{ P2 } & \multicolumn{1}{c}{ P3 } & \multicolumn{1}{c}{ P4 } & \multicolumn{1}{c}{ P5 } \\
\hline Indeks & & & $0,39 \pm$ & $0,20 \pm$ & $0,27 \pm$ \\
Kuning & $0,47 \pm$ & $0,34 \pm$ & $0,04^{\mathrm{b}}$ & $0,05^{\mathrm{e}}$ & $0,05^{\mathrm{d}}$ \\
Telur (IKT) & $0,02^{\mathrm{a}}$ & $0,04^{\mathrm{c}}$ & & & \\
Indeks & $0,095 \pm$ & $0,065 \pm$ & $0,080 \pm$ & $0,030 \pm$ & 0,045 \\
Putih Telur & $0,003^{\mathrm{a}}$ & $0,002^{\mathrm{c}}$ & $0,002^{\mathrm{b}}$ & $0,003^{\mathrm{e}}$ & \pm \\
(IPT) & & & & & $0,005^{\mathrm{d}}$ \\
& $7,00 \pm$ & $8,20 \pm$ & $7,70 \pm$ & $9,60 \pm$ & $8,80 \pm$ \\
pH Telur & $0,03^{\mathrm{a}}$ & $0,05^{\mathrm{c}}$ & $0,05^{\mathrm{b}}$ & $0,05^{\mathrm{e}}$ & $0,04^{\mathrm{d}}$ \\
\hline
\end{tabular}


Keterangan: angka yang diikuti superskrip yang berbeda pada baris yang sama menunjukan hasil yang berbeda nyata $(\mathrm{P}<0,05)$.

Kondisi lingkungan yang diamati selama penelitian yaitu meliputi suhu dan kelembaban relatif ruang penyimpanan. Suhu rata rata pada pagi hari adalah $27^{\circ} \mathrm{C}$ dengan kelembaban relatif 80 $\%$, pada siang hari suhu rata rata ruangan sebesar $30^{\circ} \mathrm{C}$ dengan kelembaban relatif $72 \%$ dan pada sore hari sebesar $28^{\circ} \mathrm{C}$ dengan kelembaban relatif $83 \%$ sedangkan rata rata suhu dan kelembaban relatif secara keseluruhan adalah $27,5^{\circ} \mathrm{C}$ dan 81 $\%$. Telur segar yang disimpan pada suhu kamar dengan kelembaban relatif berkisar $80 \%$ maksimum hanya mampu bertahan selama 14 hari penyimpanan. Suhu dan kelembaban relatif selama penyimpanan telur perlu untuk diketahui karena dua hal tersebut termasuk dalam faktor yang berperan dalam penurunan kualitas telur selama penyimpanan. Suhu ruang yang cukup tinggi mengakibatkan telur hanya mampu bertahan selama 14 hari setelah peneluran. Menurut BSN (2008) penyimpanan telur konsumsi yang ideal adalah pada suhu $27^{\circ} \mathrm{C}$ dengan kelembaban relatif $60 \%$. Menurut USDA (2000) faktor faktor yang mempengaruhi penurunan kualitas telur adalah umur simpan, tekstur kerabang, suhu dan kelembaban relatif selama penyimpanan.

Hasil penelitian menunjukkan $\mathrm{pH}$ telur, Indeks Kuning Telur dan Indeks Putih Telur kelompok P4 berbeda nyata dengan kelompok P1 dan kelompok P2. Indeks Kuning Telur, $\mathrm{pH}$ telur dan Indeks Putih Telur antar perlakuan kelompok P2 dan kelompok P3 berbeda nyata. kelompok P4 dan kelompok P5 berbeda nyata.

Hasil penelitian menunjukkan IPT pada P4 dan P5 berbeda nyata dengan P1.Hal ini menunjukkan semakin lama penyimpanan nilai IPT akan semakin menurun. Hal ini menurut Cornelia (2014) terjadi akibat adanya penguapan air dan gas seperti $\mathrm{CO}_{2}$ yang menyebabkan putih telur kental menjadi semakin encer. Akyurek and Okur (2009) menunjukkan lama penyimpanan berakibat terjadi penurunan IPT. Hal ini akibat dari kenaikan $\mathrm{pH}$ putih telur menjadi semakin encer, tinggi putih telur kental menurun dan nilai IPT semakin kecil.

Indeks Putih Telur pada kelompok telur yang sebelum disimpan direndam dahulu pada air kapur berbeda nyata dengan kelompok telur yang sebelum disimpan tidak direndam pada air kapur. Hal ini menunjukkan perendaman air kapur menghambat penguapan pada telur. Menurut Koswara (2009) air kapur membentuk lapisan pada kulit telur sehingga akan mencegah penguapan gas dan keluarnya air dari dalam telur.

Hasil penelitian menunjukkan $\mathrm{pH}$ telur pada P4 dan P5 berbeda nyata dengan P1. Hal ini menunjukkan semakin lama penyimpanan $\mathrm{pH}$ telur akan semakin naik. Menurut Cornelia (2014) perubahan kandungan $\mathrm{CO}_{2}$ dalam putih telur akan mengkibatkan perubahan $\mathrm{pH}$ putih telur menjadi basa. Hal tersebut sesuai dengan pendapat (Jazil, 2013) yang menyatakan bahwa $\mathrm{CO}_{2}$ yang hilang melalui pori kerabang telur mengakibatkan konsentrasi ion bikarbonat dalam putih telur menurun dan merusak sistem buffer. Hal tersebut menjadikan $\mathrm{pH}$ naik dan putih telur bersifat basa yang diikuti dengan kerusakan serabut serabut ovomucin (yang memberikan tekstur kental), sehingga kekentalan putih telur menurun.

$\mathrm{pH}$ telur pada kelompok telur yang sebelum disimpan direndam dahulu pada air kapur berbeda nyata dengan kelompok telur yang sebelum disimpan tidak direndam pada air kapur. Menurut Koswara (2009) perendaman air kapur menyebabkan kenaikan kenaikan $\mathrm{pH}$ pada permukaan kulit telur yang dapat menghambat pertumbuhan mikroba. Terhambatnya pertumbuhan mikroba menyebabkan telur tidak mudah rusak.

Hasil penelitian menunjukkan bahwa semakin lama penyimpanan nilai IKT semakin menurun. Menurut Cornelia (2014) bertambahnya umur telur nilai IKT semakin menurun. Indeks kuning telur menurun karena penambahan ukuran kuning telur sebagai akibat perpindahan air. Pada telur segar posisi kuning telur di tengah, makin lama penyimpanan posisi kuning telur akan bergeser ke pinggir, bahkan semakin lama telur disimpan kuning telur akan pecah yang disebabkan pecahnya membran vitelin karena penurunan elastisitasnya dan penurunan kekentalan putih telur. 
Hasil penelitian menunjukkan telur yang direndam pada air kapur menunjukkan perlambatan penurunan nilai IKT pada telur yang direndam pada air kapur. Menurut Koswara (2009) daya pengawet dari kapur karena mempunyai sifat basa, sehingga mencegah tumbuhnya mikroba. Kapur $(\mathrm{CaO})$ akan bereaksi dengan udara membentuk lapisan tipis kalsium karbonat $(\mathrm{CaCO} 3)$ di atas permukaan cairan perendam. Kemudian $\mathrm{CaCO} 3$ yang terbentuk akan mengendap di atas permukaan telur, membentuk lapisan tipis yang menutupi pori. Kapur juga menyebabkan kenaikan kenaikan $\mathrm{pH}$ pada permukaan kulit telur yang dapat menghambat pertumbuhan mikroba.

\section{KESIMPULAN}

Perendaman pada air kapur mampu menghambat penurunan kualitas telur yang ditunjukkan dengan nilai $\mathrm{pH}$ telur, Indeks Kuning Telur dan Indeks Putih Telur pada tiap kelompok hari penyimpanan

\section{DAFTAR PUSTAKA}

Akyurek, H.and A.A. Okur. 2009. Effect of Storage Time, Temperature and Hen Age on Egg Quality in Free-Range Layer Hens. Journal of Animal and Veterinary Advances. 8(10): 1953-1958

Badan Standarisasi Nasional (BSN). 2008. SNI 3926:2008 Telur AyamKonsumsi. BSN, Jakarta.

Cornelia, A., I. K. Suada, M. D. Rudyanto. 2014. Perbedaan Daya Simpan Telur Ayam Ras yang Dicelupkan dan Tanpa Dicelupkan Larutan Kulit Manggis. Indonesia Medicus Veterinus 3(2): 112-119.

Djaelani, M.A. 2015. Pengaruh Pencelupan pada Air Mendidih dan Air Kapur Sebelum Penyimpanan Terhadap Kualitas Telur Ayam Ras (Gallus L.).Buletin Anatomi dan Fisiologi 23(1) : 24-30
Djaelani, M.A. 2017. Kualitas Telur Puyuh Jepang (Coturnix coturnix japonica L.) Berdasarkan Variabel pH Telur, Kandungan Protein Telur dan Indeks Putih Telur setelah dilakukan Pencucian dan disimpan Selama Waktu Tertentu. Buletin Anatomi dan Fisiologi 2(1) : 26-30

Fibrianti, S.M., I. K. Suada, M. D. Rudyanto.2012.Kualitas Telur Ayam Konsumsiyang dibersihkan dan tanpa dibersihkan Selama Penyimpanan Suhu Kamar .Indonesia Medicus Veterinus 1(3):408- 416.

Hanafiah, K.A. 2014. Rancangan Percobaan Teori dan Aplikasi. edisi ke tiga Raja Grafindo Persada, Jakarta.

Haryono. 2000. Langkah-langkah Teknis Uji Kualitas Telur Konsumsi Ayam Ras Temu Teknis Fungsional non Peneliti. Balai Penelitian Ternak, Bogor.

Haryoto. 2010. Membuat Telur Asin. Kanisius. Yogyakarta.

Koswara, S. 2009. Teknologi Pengolahan Telur. ebookpangan.com.

Listyowati, E. 2009. Tatalaksana Budidaya Puyuh Secara Komersial. Penebar Swadaya. Jakarta.

Melia S.Juliyarsi I.Africon. 2009. Teknologi Pengawetan Telur Ayam Ras Dalam Larutan Gelatin Dari Limbah Kulit Sapi. (Laporan Penelitian Dosen Muda). Fakultas Peternakan Universitas Andalas, Surabaya.

Santoso, S. Menguasai SPSS 22. 2015. Jakarta : PT Elex Media Komputindo.

United States Departement of Agriculture (USDA). 2000. gerading Manual Agricultural Handbook number 75, Washington DC. 